\title{
ПРЕДЕЛЬНЫЕ КОЭФФИЦИЕНТЫ АКТИВНОСТИ И ИЗБЫТОЧНЫЕ ТЕРМОДИНАМИЧЕСКИЕ ФУНКЦИИ СМЕШЕНИЯ НЕКОТОРЫХ ОРГАНИЧЕСКИХ СОЕДИНЕНИЙ В ПРОПИЛФЕНИЛКЕТОНЕ
}

J. ARRO, Marii VIKS, V. TALVES. MONINGATE ORGAANILISTE OHENDITE AKTIIVSUSTEGURID LOPMATUL LAHJENDUSEL JA TERMODUNAAMILISED LIIGFUNKTSIOONID PROPOOLFENOOLKETOONIS

J. ARRO, Marii VIKS, V. TALVES. ACTIVITY COEFFICIENTS AT INFINITE DILUTION AND EXCESS THERMODYNAMIC FUNCTIONS OF SOME ORGANIC COMPOUNDS IN PROPYL PHENYLKETONE

\section{(Представил О. Эйзен)}

В настоящем сообщении приводятся результаты экспериментального определения коэффициентов активности при бесконечном разбавлении $\left(\gamma^{\infty}\right) 24$ органических соединений в пропилфенилкетоне. Выбор объектов исследования обусловлен моделированием систем, встречающихся в технологии сланцевой смолы и нефти.

Таблица 1

Коэффициенты $\boldsymbol{a}$ и $\boldsymbol{b}$ уравнения (1) и абсолютные удерживаемые объемы $\left(V^{0}\right)$ при 298 К для систем с пропилфенилкетоном

\begin{tabular}{|c|c|c|c|c|}
\hline Соединение & $\begin{array}{l}\text { Число } \\
\text { точек }\end{array}$ & $-a \pm s_{a}$ & $b \pm s_{b}$ & $\begin{array}{c}V_{g}^{0}, \\
\mathrm{M}^{3} / \mathrm{Kr}\end{array}$ \\
\hline Гексан & 14 & $5,68 \pm 0,50$ & $3280 \pm 155$ & 0,206 \\
\hline Гептан & 13 & $5,81 \pm 0,20$ & $3650 \pm 61$ & 0,619 \\
\hline Октан & 17 & $5,60 \pm 0,23$ & $3910 \pm 75$ & 1,852 \\
\hline 1-Гексен & 14 & $6,31 \pm 0,45$ & $3520 \pm 141$ & 0,242 \\
\hline 1-Гептен & 21 & $5,48 \pm 0,17$ & $3600 \pm 55$ & 0,734 \\
\hline 1-Октен & 12 & $5,27 \pm 0,43$ & $3840 \pm 141$ & 2,057 \\
\hline Циклогексан & 16 & $5,19 \pm 0,19$ & $3360 \pm 59$ & 0,434 \\
\hline $\begin{array}{c}\text { транс-1,4-Диметил- } \\
\text { циклогексан }\end{array}$ & 6 & $4,87 \pm 0,21$ & $3650 \pm 66$ & 1,625 \\
\hline $\begin{array}{c}\text { цис-1,4-Диметил- } \\
\text { циклогексан }\end{array}$ & 6 & $4,95 \pm 0,21$ & $3750 \pm 69$ & 2,074 \\
\hline Бензол & 19 & $5,45 \pm 0,21$ & $3730 \pm 69$ & 1,177 \\
\hline Толуол & 6 & $6,13 \pm 0,34$ & $4290 \pm 110$ & 3,912 \\
\hline Метиловый спирт & 39 & $6,92 \pm 0,18$ & $3660 \pm 57$ & 0,213 \\
\hline Этиловый спирт & 27 & $7,05 \pm 0,17$ & $3920 \pm 54$ & 0,457 \\
\hline Изопропиловый спирт & 11 & $8,16 \pm 0,46$ & $4350 \pm 145$ & 0,635 \\
\hline Ацетон & 16 & $6,06 \pm 0,30$ & $3570 \pm 9$ & 0,372 \\
\hline Этилащетат & 19 & $6,01 \pm 0,30$ & $3820 \pm 10$ & 0,900 \\
\hline Этиловый эфир & 25 & $4,80 \pm 0,25$ & $2890 \pm 80$ & 0,135 \\
\hline Тетрагидрофуран & 14 & $5,56 \pm 0,17$ & $3670 \pm 56$ & 0,871 \\
\hline Нитрометан & 15 & $4,95 \pm 0,66$ & $3690 \pm 211$ & 1,678 \\
\hline Метилен хлористый & 20 & $5,29 \pm 0,13$ & $3370 \pm 46$ & 0,409 \\
\hline Хлороформ & 18 & $6,06 \pm 0,19$ & $3900 \pm 59$ & 1,179 \\
\hline $\begin{array}{l}\text { Четыреххлористый } \\
\text { углерод }\end{array}$ & 13 & $5,70 \pm 0,19$ & $3680 \pm 60$ & 0,758 \\
\hline Тиофен & 16 & $5,62 \pm 0,36$ & $3880 \pm 115$ & 1,619 \\
\hline Пирндиң & 6 & $6,85 \pm 0,33$ & $4650 \pm 107$ & 6,307 \\
\hline
\end{tabular}


Предельные коэффициенты активности определяли газохроматографически по методике $\left[{ }^{1-3}\right]$. Измерения проводили на хроматографе «Вырухром» с усовершенствованными системами термостатирования колонки и измерения давления газа-носителя (гелия) на входе в колонку. Неподвижную жидкую фазу (пропилфенилкетон ч.) наносили на Инертон AW-HMDS диаметром 0,16-0,20 мм в количестве $15-20 \%$. Измерения проводили в области температур 293-340 K, температуру колонки (нержавеющая сталь, $1000 \times 4$ мм) поддерживали с точностью $\pm 0,05 \mathrm{~K}$.

Необходимые в расчетах данные о давлении насыщенных паров и энтальпии испарения сорбатов определяли по данным [4,5], используя уравнение Антуана с тремя константами.

Найдено, что во всех исследованных системах зависимость $\ln V_{g}^{0}$ от обратной температуры хорошо ( $r \geqslant 0,99$, для нитрометана $r=0,98)$ описывается уравнением прямой

$$
\ln \mathrm{V}_{\mathrm{g}}^{0}=a+b / T .
$$

Значения коэффициентов $a$ и $b$ (табл. 1) использовали для интерполяции величин $V_{\mathrm{g}}^{0}$ до $298,2 \mathrm{~K}$, на основе которых рассчитывали значения $\gamma^{\infty}$ растворенных соединений (сорбатов) в пропилфенилкетоне. Отсутствие заметного систематического отклонения экспериментальных величин $V_{g}^{0}$ от рассчитанных по уравнению (1) указывает на то, что энтальпия растворения сорбатов в жидкой фазе $\left(\Delta H_{S}\right)$. действительно

Таблица 2

Энтальпия растворения, избыточные термодинамические функции смешения и коэффициенты активности органических соединений при бесконечном разбавлении в пропилфенилкетоне при 298 К

\begin{tabular}{|c|c|c|c|c|c|}
\hline \multirow{2}{*}{ Соединение } & $\Delta H_{s}$ & $\bar{G}^{E}$ & $\bar{H}^{E}$ & \multirow{2}{*}{$\begin{array}{c}\bar{S}^{E}, \\
\text { Дж/моль } \cdot \mathrm{K}\end{array}$} & \multirow{2}{*}{$\gamma^{\infty}$} \\
\hline & \multicolumn{3}{|c|}{ кДж/моль } & & \\
\hline Гексан & 27,3 & 3,24 & 4,74 & 5,05 & 3,69 \\
\hline Гептан & 30,4 & 3,48 & 6,52 & 10,20 & $\begin{array}{l}0,09 \\
4,06\end{array}$ \\
\hline Октан & 32,5 & 3,70 & 9,42 & $\begin{array}{l}10,20 \\
19,19\end{array}$ & $\begin{array}{l}4,00 \\
4,45\end{array}$ \\
\hline 1-Гексен & 29,3 & 2,33 & 1,91 & $-1,41$ & 2,56 \\
\hline 1-Гептен & 29,9 & 2,53 & 5,93 & 11,40 & 2,78 \\
\hline 1-Октен & 31,9 & 2,89 & 8,75 & 19,65 & 3,21 \\
\hline Циклогексан & 27,9 & 2,48 & 5,37 & 9,72 & 2,71 \\
\hline $\begin{array}{c}\text { транс-1,4-Диметил- } \\
\text { циклогексан }\end{array}$ & 30,4 & 2,82 & 7.82 & & \\
\hline $\begin{array}{c}\text { цис-1,4-Диметил- } \\
\text { циклогексан }\end{array}$ & 31,2 & $\begin{array}{l}2,02 \\
2,80\end{array}$ & 8,20 & $\begin{array}{l}16,16 \\
18,10\end{array}$ & $\begin{array}{l}3,12 \\
3,10\end{array}$ \\
\hline Бензол & 31,0 & 0,07 & 3,09 & 10,14 & 1,03 \\
\hline Толуол & 35,7 & $-0,54$ & 2,62 & 10,61 & 0,80 \\
\hline Метиловый спирт & 30,5 & 3,63 & 8,41 & 16,01 & 4,32 \\
\hline Этиловый спирт & 32,6 & 3,56 & 9,80 & 20,92 & 4,21 \\
\hline Изопропиловый спирт & 36,2 & 3,91 & 8,78 & 16,34 & 4,83 \\
\hline $\begin{array}{l}\text { Ацетон } \\
\text { Этилацетат }\end{array}$ & 29,7 & 0,72 & 2,08 & 4,54 & 1,34 \\
\hline $\begin{array}{l}\text { Этилацетат } \\
\text { Этиловый эфир }\end{array}$ & 31,8 & 0,74 & 4,14 & 11,41 & 1,35 \\
\hline $\begin{array}{l}\text { Этиловый эфир } \\
\text { Тетрагидрофуран }\end{array}$ & 24,0 & 1,20 & 4,43 & 10,83 & 1,62 \\
\hline $\begin{array}{l}\text { Тетрагидрофуран } \\
\text { Нитрометан }\end{array}$ & 30,5 & $-0,51$ & 1,87 & 8,00 & 0,81 \\
\hline $\begin{array}{l}\text { Нитрометан } \\
\text { Метилен хлористый }\end{array}$ & 30,7 & 1,62 & 7,82 & 20,78 & 1,92 \\
\hline $\begin{array}{l}\text { Метилен хлористый } \\
\text { Хлороформ }\end{array}$ & 28,0 & $-1,05$ & 1,23 & 7,65 & 0,65 \\
\hline $\begin{array}{l}\text { Алороформ } \\
\text { Четыреххлористый } \\
\text { углерол }\end{array}$ & $\begin{array}{l}32,5 \\
30,6\end{array}$ & $\begin{array}{r}-1,71 \\
0,70\end{array}$ & $\begin{array}{r}-0,08 \\
2,04\end{array}$ & $\begin{array}{l}5,46 \\
4,50\end{array}$ & $\begin{array}{l}0,50 \\
1,33\end{array}$ \\
\hline Тиофен & 32,3 & $-0,28$ & 2,68 & 9,94 & 0.89 \\
\hline Пиридин & 38,7 & $-0,22$ & 2,26 & 8,31 & 0,92 \\
\hline
\end{tabular}


является величиной постоянной и, следовательно, температурную зависимость $V_{g}^{0}$ можно использовать для расчета парциальных термодинамических величин.

Сопоставление значений избыточной энтальпии $\left(\bar{H}^{E}\right)$ и избыточной энтропии смешения $\left(\bar{S}^{E}\right)$ (см. табл. 2) показывает, что между ними имеется существенная линейная корреляция $(r=0,87)$.

\section{Л И Т Е Р А Т У РА}

1. Мельдер Л. И., Метлицкая О. Ф. Предельные коэффициенты активности органических соединений в некоторых фенолах, кетонах и эфирах. - Ж. прикл. хим., 1985,58 , № $8,1928-1930$.

2. Арро Я. Применение обращенной газовой хроматографии в исследовании тяжелой смолы сланца-кукерсита. - Изв. АН ЭССР. Хим., 1982, 31, № 3, 163-168.

3. Арро М. А. Избыточные термодинамические функции смешения органических растворителей с 3,5-диметоксибензолом. - Тр. Таллин. политехн. ин-та, 1981, № $509,59-66$.

4. Handbook of Chemistry and Physics. 57th ed. Cleveland (Ohio), 1976-1977.

5. Lange's Handbook of Chemistry. 12th ed. New York-St. Louis, et al., 1979.

\section{Институт химии}

Академии наук Эстонской ССР
Поступила в редакцию 25/XI 1985 